\title{
Innovative means of energy efficiency management for regional industrial enterprises
}

\author{
Olga Maksimchuk ${ }^{1}$, and Tatyana Pershina ${ }^{1 *}$ \\ ${ }^{1}$ The department of management and urban development and construction, Volgograd State Technical University, Volgograd, \\ Russia
}

\begin{abstract}
Currently in the Russian Federation one of the most important strategic goals set by the President of the Russian Federation, is to reduce by 2020 energy intensity of domestic economy by $40 \%$. On the way to achieving this goal, all organizations (institutions) of business, government, society and households should be energy efficient. The paper dwells upon the problem of rational use of energy by regional enterprises. It discusses the theoretical and methodological aspects of developing software that combines the functionality of a training program for beginners and that of universal assistant for energy audit and management practitioners. «sto: Energoauditor.1» has been tested by budget-funded companies and enterprises in Volgograd Oblast to prove the feasibility of using it for making energy audits or filling energy declarations.
\end{abstract}

\section{Introduction}

Currently, one of the most important strategic purposes set by the President of the Russian Federation, is to reduce the energy intensity of the national economy by 2020 by $40 \%$. Towards achieving this purpose, all companies (institutions) of business, government, the community and the household must be energy efficient [1]. Energy auditing survey, as one of the main tools of the movement to energy efficiency, does not allow to organize continuous monitoring and energy analysis, which are not free of errors, mistakes, subjective assessment and corruption schemes in implementation so the alternative methods and energy saving management tools are necessary at the local level [2].

The appeal to this theme is also due to problems and trends in the development of modern society, taking into account the priorities of energy saving and energy efficiency of vital activity. According to the assessments of International Energy Agency, the sizes of the effect from energy saving are equivalent to almost $2 / 3$ of the export of natural gas in Russia [3].

The results analysis of implementation of the Federal Law of November 23, 2009 no. 261 "About energy saving and energy efficiency increase and about changes in certain legislative acts of the Russian Federation" has shown the failure of some of the requirements.

In particular it concerns the realization of energy audit surveys. According to the LLC "Center of Energy Efficiency INTER RAO EES", the proportion of companies is no more than one-third which is obliged by the law to carry out mandatory energy audits and actually carried it out.
In the Energy Ministry only $10 \%$ of the total received energy passports are registered without comment. All the rest are returned on completion. Often the cause of low audit quality is the choice of unqualified executor that, in turn, happens because of a lack of skilled customer approach to the selection of executor and to control its operation [4].

But it's not the only problem faced to the executive authorities of the R.F. which are responsible for the law implementation. Companies and enterprises in the region are engaged in energy saving by exploiting the old equipment, technologies and they do not seek to develop innovative products and services [5].

To increase the activity and the quality of decisions in the sphere of energy-saving, Energy Ministry of Russia proposes to introduce the rating system of the energy efficiency levels in the regions, based on the offbudget financing of energy-saving programs. 4.94 billion rubles were allocated in 2014 for the development of the state program "Energy efficiency and energy development" in 25 regions [6].

There is necessary to be the leader of the rating to be included in the number of funded regions. But how to achieve this? What actions are necessary to do for this purpose? And what tools to use? In this article, the authors offer answers to these questions.

The need for increasing the effectiveness of the law implementation at all levels of the government has demanded the increase of the specialists' qualification level in the sphere of energy saving and energy management and the development of appropriate instruments to improve energy efficiency of enterprises

\footnotetext{
Corresponding author: tatpersh@yandex.ru
} 
and companies of the region, that determined the relevance of this article.

\section{The theoretical rationale of tool development expediency of energy efficiency increase in the industrial enterprises}

From the standpoint of a systemic and integrated approach the authors fully explore the problem of energy management development at the level of enterprises and companies, the private moments, such as energy auditing survey and the development of energy efficiency programs, which are paid more attention to the practice $[7,8,9,10,11,12,13]$.

In earlier publications, the authors present the results of the development of energy-economic survey techniques, allowing to realize the survey by the enterprise experts. The survey covers the full cycle of energy expenses management and it is the important management tool which does not require capital expenditures and outsourcing specialists (as in the case of energy audit survey) $[14,15,16]$.

The methodology of energy-economic survey complements the current existing energy audit methodology and software to it in terms of the detail of all the procedures of: 1) energy survey; 2) preparing to the report of energy auditor; 3) development of a comprehensive energy efficiency program.

The first two sets of procedures are sufficiently formalized, but in practice there are non-standard situations, requiring adaptation to the traditional approach to the conditions, such as lack of comparable retrospective measurement base for the company, which rents the room and change location every year. Also the industry aspects are important, which requires skill and qualification level of energy auditors [17].

On average, according to the subjective opinion of the authors and calculations made on the basis of observations in the course of energy auditing and survey work on its own, the loss of time related with the rectification, recalculations, rechecking, arising due to the above circumstances, are $40-50 \%$ of the total time spent on energy audits and preparation for the report.

With regard to energy efficiency programs, the content analysis of available energy audit reports in Internet resources, suggests replicating of the typical energy saving measures in the most cases (for example, with the phrases "energy saving lamps", "installation of energy-saving / plastic window frames", "facade insulation " 95\% of passports are mentioned).

Typical activities do not always and necessarily lead to the realization of energy saving effect and, in some cases, directly affect the growth of the energy losses $[18,19,20]$.

The author's approach to the development of energy efficiency programs is fundamentally different from the widely practiced: Energy Efficiency Program - a set of investment and innovative solutions and measures to ensure their implementation in the short, medium, longterm periods, taking into account the actual conditions and opportunities for the implementation of funds from the cumulative effect of fast payback measures.

The subject of researches are the conditions and prerequisites for the optimization of energy saving management, the object of the study are the technicaltechnological and economic aspects of the organization of energy management at the level of companies and enterprises of the region.

Thus, the author's approach allows to resolve the conflict between the regulatory requirements and the real conditions, to harmonize technical requirements of energy audit and economic requirements of energy efficient program development. This tool is management software of local energy efficiency. A particular advantage is the ability to comply with the requirements of confidentiality. Currently, energy-economic survey methodology has the status of "know-how" and the software "sto: Energoauditor.1" - the Certificate of the state registration of the computer program number 2013614783, " sto: Energoauditor.1".

It would be logical to use those software products that are being already developed, but their analysis showed that, unfortunately, none of the existing software matches in full the demands made on them. For example, ARM SRO "Energy Passport" allows only to fill the energy passport and has no additional functions automation calculations, conversion to TOE etc. More successful software product is an automatic working place «E-Pass», which is intended for automation of energy auditors' work for the formation of energy audits results, but it is not suitable for the realization of energy expenses control function in the enterprise.

There are foreign software products in the Russian market, such as AMR (Automatic Meter Reading), PLC (Power Line Communication), ENSI (Energy Saving International), Smart Grid and their localized Russian versions are created $[21,22,23]$.

However, the work with these products is available only to trained specialists- energy auditors, and the authors initially set a goal - to develop software as a tool of local energy efficiency management, that is, directly at the level of companies (institutions) and business enterprises, government, the society and households.

\section{The results of software development}

In the basis of the software product "sto: Energoauditor.1" is the DBMS Firebird, which is free for the distribution and use, and is ideal for the combination of factors: ease of maintenance / free / speed (much higher Access). The DBMS Firebird offers concurrency, high efficiency, and language support for stored procedures and triggers. This is a commercially independent project of $\mathrm{C}$ and $\mathrm{C}++$ programmers, technical advisors and supporters of the formation and strengthening of multi-platform management systems of relational databases, based on the source code released by Inrise Corporation (now known as BORLAND SOFTWARE.

FireBird - developed industrial software, guaranteeing transactional integrity of the data when 
using it with multiple users, corresponding to the ACID rules:

1.Atomicity - atomicity of transactions;

2.Consistency - data integrity;

3.Isolation - isolation (user access control);

4.Durability - long duration of data storage [24].

The software designed by the authors can work with the use of a DBMS FireBird:

1) locally, independently of any installed programs, with its database (Firebird Embedded Server mode);

2) in a network with a single base passport data (requires server installation and configuration of client connections);

3) when it is necessary to organize the work via the Internet (with a base located on an accessible server). Customers can work with a single database of passports from anywhere.

The software allows to prevent the likelihood of technical and computational errors and reduces the time required for data processing and preparation of the conclusion.

The advantages can also include:

1) it is an effective tool for training the specialists of energy audit and energy management at the expense of function simulation of practical situation with specified parameters, that is an effective training for audience;

2) it allows to optimize the cost of the survey, compared with the involvement of external energy auditor;

3 ) it increases the qualification level of employees in the learning process.

The software product "sto: Energoauditor.1" has several beneficial features that distinguish it from other types of software. The first important feature is the function of filling the energy declarations by companies of budget sphere.

Energy declaration is document containing information about energy consumption in the organization of budget sphere during the year, taking into account program obligations improving energy efficiency. Declaration is filled every year after the end of the calendar year by the person who is responsible for energy saving and energy efficiency increasing of company, separately for each building and structures. They are much easier to fill than the energy audit passports, and it is intended that the companies financed from the budget have to do it by themselves, it will bring the cost savings.

However, in practice, the institutions face with difficulties, which helps to solve the software product "sto: Energoauditor.1". It operates the online help system, which contains the legal and background information, legal acts and standards, which help specialist / user to orientate freely with warning about error probability in the vast amount of regulatory information. In addition, the "one hundred: Energy auditor.1" gives a choice probability of a universal energy-saving program precisely those activities that are suitable for the enterprise, as well as filling the energy passport / energy declaration in accordance with the requirements of the Russian Ministry of Energy.
The using of software allows to make the registration process of the survey results / the filling of energy declarations more convenient and simpler, that allows to reduce expenses and to improve the efficiency of enterprises and companies of different ownership forms.

Today using the software " sto: Energy auditor.1" in accordance with the requirements of the Federal Law of November 23, 2009 N 261-FZ "About energy saving and energy efficiency increase and about changes in certain legislative acts of the Russian Federation", the authors developed and implemented the training programs for young specialists (bachelors, masters) and practitioners. Program sets of higher education and qualification increase are shown in Fig. 1 according to the energy management profiles.

\section{DEVELOPED COURSES}

\begin{tabular}{|c|c|}
\hline BACHELOR'S AND & ENERGY EXPERTS \\
MASTER'S & \\
\hline TRAINING & TRAINING \\
+ & + \\
SOFTWARE & SOFTWARE PRODUCT \\
PRODUCT & + \\
+ & FREE TECHNICAL \\
IMITATION & SUPPORT \\
MODELING & + \\
& CONSULTING \\
& SUPPORT \\
\hline
\end{tabular}

Fig. 1. The program sets of higher education and qualification increase according to the energy management profiles.

In addition, the simulation modeling function of practical situations is built-in the software product (e.g. there is the task of the realization of energy audit survey according to the set parameters). This situation allows to combine the functions of the simulator for beginners and the universal assistant for practitioners in energy audit and energy management.

\section{The results of software product approbation «sto: Energoauditor.1»}

As a result of the partial approbation of the proposed software product for improvement the energy efficiency in the various companies and enterprises in the region (on materials of the Volgograd area) the audience of the training programs has implemented the energy savings potential assessments and has developed the energy efficiency Programs (Table. 1).

Table 1. The exapmle of the energy saving potential assessment of the enterprises of different ownership.

\begin{tabular}{|c|l|l|l|l|l|}
\hline Companies & Dime \\
& nsion & \multicolumn{5}{|c|}{ Energy saving potential } \\
\cline { 3 - 6 } & & Total & $\begin{array}{l}\text { Heat } \\
\text { energy }\end{array}$ & $\begin{array}{l}\text { Electric } \\
\text { energy }\end{array}$ & Fuel \\
\hline \multicolumn{6}{|c|}{ Consumers } \\
\hline $\begin{array}{c}\text { «Volgograd } \\
\text { Building } \\
\text { Technical } \\
\text { College» }\end{array}$ & TOE & 28.11 & 24.49 & 3.62 & - \\
\cline { 3 - 6 } & Rub. & 269.69 & 206.99 & 62.704 & - \\
\hline
\end{tabular}




\begin{tabular}{|c|c|c|c|c|c|}
\hline \multirow{2}{*}{$\begin{array}{c}\text { «ryupinsky } \\
\text { agro- } \\
\text { industrial } \\
\text { Technical } \\
\text { College» }\end{array}$} & TOE & 42.44 & 21.26 & 21.18 & - \\
\hline & Rub. & 439.84 & 179.31 & 260.53 & - \\
\hline $\begin{array}{l}\text { LLC } \\
\text { «Electrostroy } \\
\text { snab» }\end{array}$ & Rub. & 2708.9 & 1251.5 & 1457.4 & - \\
\hline \multicolumn{6}{|c|}{ Distributors } \\
\hline \multirow{2}{*}{$\begin{array}{c}\text { Management } \\
\text { company } \\
\text { LLC } \\
\text { «Zhilcomser } \\
\text { vice» } \\
\end{array}$} & TOE & 38.39 & 29.07 & 9.32 & - \\
\hline & Rub. & 387.6 & 259.64 & 127.96 & - \\
\hline \multirow{2}{*}{$\begin{array}{l}\text { Homeowners } \\
\text { «Zhilservice» }\end{array}$} & TOE & 26.67 & 19.01 & 7.66 & - \\
\hline & Rub. & 265.90 & 202.02 & 63.884 & - \\
\hline \multirow{2}{*}{$\begin{array}{c}\text { Management } \\
\text { company } \\
\text { LLC «Our } \\
\text { House» }\end{array}$} & TOE. & 68.49 & 68.49 & - & - \\
\hline & Rub. & 473.31 & 473.31 & - & - \\
\hline \multicolumn{6}{|c|}{ Suppliers of communal services } \\
\hline \multirow{2}{*}{$\begin{array}{c}\text { CBM } \\
\text { «Volgograd } \\
\text { utilities» }\end{array}$} & TOE & 4185.3 & 4086.4 & 357.68 & 258.8 \\
\hline & Rub. & 41643.9 & 34530.5 & 4399.5 & 2713 \\
\hline
\end{tabular}

(Source: compiled on the basis of authors' calculations)

Currently, the developed energy saving programs implemented at listed enterprises and companies in the Table 1. The example of energy saving measures Program of "Elektrostroysnab" is presented in Table 2.

Table 2. The example of the energy saving measures program of the LLC "Electrostroysnab"

\begin{tabular}{|c|c|c|c|}
\hline $\begin{array}{l}\text { Description of } \\
\text { measures }\end{array}$ & $\begin{array}{c}\text { The } \\
\text { annual } \\
\text { economic } \\
\text { effect, } \\
\text { thous.rub. }\end{array}$ & $\begin{array}{c}\text { Payback } \\
\text { period, } \\
\text { years }\end{array}$ & $\begin{array}{l}\text { The cost } \\
\text { of } \\
\text { measures, } \\
\text { thous.rub. }\end{array}$ \\
\hline \multicolumn{4}{|c|}{ Average payback measures } \\
\hline $\begin{array}{c}\text { Cogeneration } \\
\text { installation } \\
\text { Viessmann Vitobloc } \\
200 \\
\end{array}$ & 1400 & 2.32 & 3250 \\
\hline $\begin{array}{c}\text { Thermorenovation of } \\
\text { administrative } \\
\text { building }\end{array}$ & 210.1 & 2.1 & 441.755 \\
\hline $\begin{array}{c}\text { Installation of } \\
\text { photovoltaic roof tiles } \\
\text { TEGOSOLAR } \\
\end{array}$ & 392.4 & 2.9 & 1150.6 \\
\hline $\begin{array}{l}\text { Installation radiator } \\
\text { thermostats RA-N20 }\end{array}$ & 114.9 & 2.5 & 287.6 \\
\hline \multicolumn{4}{|c|}{ Long-term measures } \\
\hline Installation turbines & 152 & 3,6 & 548 \\
\hline $\begin{array}{l}\text { The introduction of } \\
\text { commercial } \\
\text { accounting of electric } \\
\text { power automated } \\
\text { system }\end{array}$ & 439.59 & 3.25 & 1430 \\
\hline IN TOTAL & 2708.99 & & 7107.955 \\
\hline
\end{tabular}

(Source: compiled on the basis of authors' calculations)

The main measures of the energy saving program (Table 2) concern the electricity energy savings, as these measures will be used as exhibition samples to potential buyers. Energy saving measures program is developed for the long term. It is planned to make a profit already in the first year in the amount of 2708.99 thousand rub. when the total expenses are 7107.955 thousand rub. In the future it is also planned to make a profit depending on the payback period of energy-saving measures.

It should be noted that some measures are not for only saving energy, but also for the good environmental situation, which, if possible, should be reflected in the total indexes.

The use of the software product, for example, during the energy audit survey in the institution "Volgograd Building Technical College" has allowed to reduce the time required to prepare a report by $36 \%$ and to save 185 thousand rubles due to the fact that the survey was conducted by the training specialists. Commercial offers from energy auditing companies ranged from 200 thousand to 275 thousand rubles, and the training of specialists according to the qualification increase program was 15 thousand rubles. The implementation of the energy saving measures Program in the companies has allowed to reduce energy expenses by $15.8 \%$ in the second year. It carried out both by own funds and through debt.

In addition, the use of software product has allowed experts of the Regional Center for Pricing Formation in Construction of Volgograd region as soon as possible to fill the energy declaration of their companies and avoid the penalties.

The software covers the full cycle of energy expenses management and is an important management tool, which received the approval from not only specialists of housing and communal services, but from enterprises of the building and the industry, that is evidenced by the conclusion of contracts and approbation applications.

But it is necessary two powers to change the problem situation. The first power - from the top, i.e. not just calls, but the real actions from the President, the government to the whole administrative system. Fortunately, there are so actions [25]. A second power is the team of trained professionals who are capable in the conditions of total energy savings to direct their companies and enterprises to a new level of energy efficiency with the help of the software product " sto: Energoauditor.1".

\section{Conclusion}

Received theoretical and methodological results have a bright practical focus and relevance, can be applied in the development process and implementation of energy savings policies aimed at the formation and effective implementation of the energy saving potential of enterprises and business companies, government, society and households in the region. The energy efficiency purposes of the national economy can be achieved as a whole only by joint efforts of energy efficiency management at their local levels. 


\section{References}

1. M. Belyaev, O. Maksimchuk, and T. Pershina, Management of energy consumption in the enterprises of housing and communal economy (VolgGASU, Volgograd, 2009)

2. S. Gheorghe, N. Golovanov, H. Albert, C. Stanescu and D. Ilisiu, Proceedings of International Conference on Harmonics and Quality of Power, ICHQP, 430 (2014)

3. V. Dobrodey, Regional Economy, 2, 220 (2015)

4. I. Bashmakov, Energy saving, 1, 29 (2011)

5. A. Semenov, Development of the economic mechanism of national innovation system functioning (Saratov, 2014)

6. N. Borisova, A. Borisov, Proceedings of the II International Scientific and Practical Conference, 13 (2015)

7. C.A. Jenne, R.K. Cattell, Energy Economics, 5, 114 (1983)

8. M. Marques, R. Neves-Silva, Journal of Cleaner Production, 88, 115 (2015)

9. Y. Kim, A. Aravkin, H. Fei, A. Zondervan, and M. Wolf, IBM Journal of Research and Development, 1 (2016)

10. V. Blass, C.J. Corbett, M.A. Delmas, and S. Muthulingam, Energy, 65, 560 (2014)

11. V.U. Baldin, N.I. Danilov, G.I. Khudyakova, WIT Transactions on Ecology and the Environment, 2, 1208 (2014)

12. G.J. Tsekouras, M.A. Tsaroucha, C.D. Tsirekis, A.D. Salis, E.N. Dialynas, and N.D. Hatziargyriou, International Journal of Electrical Power and Energy Systems, 6, 1222 (2011)
13. S. Rajabi, S. Behairy, Procedia Engineering, 1088 (2016)

14. O. Maksimchuk, T. Pershina, G. Golikova, N. Borisova, and S. Ivashova, The concept of energy saving management in housing and communal services: a systematic approach (Crouton, Volgograd, 2015)

15. T.A. Pershina, The system development of the energy expenses management in the enterprises of housing and communal services (Volgograd, 2006)

16. T.A. Pershina, Journal of Volgograd State University, 7, 133 (2008)

17. A. Thumann, Eric A. Woodroof, Handbook of financing energy projects (The Fairmont Press, Lilburn, 2005)

18. V.F. Hershkowitz, Energy-saving systems of residential buildings. Manual for designing (2008)

19. C. Diepering, I. Brand, W. Vermeulen, Energy policy, 6, 773 (2004)

20. O. Seppänen, G. Goeders, Benchmarking Regulations on Energy Efficiency of Buildings. Executive summary, 5 (2010)

21. A.G. Van Engelen, J.S. Collins, Proceedings of the Annual Hawaii International Conference on System Sciences (2010)

22. A. Al-Mofleh, S. Taib, H. Al-Gulman, Proceeding of the 5th International Symposium on Mechatronics and its Applications (2008)

23. R. Hackl, E. Andersson, S. Harvey, Chemical Engineering Transactions, 21, 301 (2010)

24. H. Borry, FireBird. Guide Database Developer (BHV-Petersburg, St. Petersburg, 2006)

25. V.V. Zubarev, V.A. Irkov, N.A. Korgin, Management problems, 1, 27 (2012) 